\title{
IMPACT OF COVID-19 PANDEMIC ON TENANCY AGREEMENT: THE LESSON FROM AN EMERGING RENTAL HOUSING MARKET IN NIGERIA
}

\author{
Anthony Ikpeme ANKELI ${ }^{1 *}$, Muhammad Bashar NUHU', \\ Naomi Ijadunola POPOOLA ${ }^{3}$, Olurotimi Adebowale KEMIKI ${ }^{4}$, \\ Sunday Okuomah OKOH $^{5}$, Joseph Olusegun OMOTEHINSHE \\ ${ }^{1}$ Department of Estate Management and Valuation, Federal Polytechnic, Ede, Nigeria \\ 2, 3 \& 4 Department of Estate Management and Valuation, Federal University of \\ Technology, Minna, Nigeria \\ ${ }^{5}$ Department of Estate Management and Valuation, Federal Polytechnic, Bida, Nigeria \\ ${ }^{6}$ Department of Building Technology, Federal Polytechnic, Ede, Nigeria \\ "Corresponding author's email: thonyankeli@gmail.com
}

\begin{abstract}
The study aimed at evaluating the contents of tenancy agreement entered into between lessors and lessees in Osogbo, Owode-Ede and Ede Metropolis in Osun State (Nigeria) from 2011 to 2020 in order to determine its adequacy in the face of the Post-COVID-19 pandemic in Nigeria. A questionnaire survey approach was adopted to achieve aim of the study. Findings of the study revealed steady dwindling of rental market transactions with deteriorating landlord/tenant relationship caused by disagreement on tenancy agreement related issues leading to default in rent payment, rent review period and renewal. Findings also indicated a low ebb experience in the rental market due to the economic downturn resulting from, among other factors, the lockdown policy, which impoverished Nigerians to the extent of struggling to make ends meet. The study further found that $86.3 \%$ of the tenancy agreements were inadequate in content and execution as basic tenants' remedial provisos were not included in most of the agreements. The study provided pertinent information that could be used as baseline information for tenancy agreement preparation, enhancing landlord (lessor) and tenant (lessee) relationship, and guiding rental real estate investment decisions in Nigeria.
\end{abstract}

Keywords: Content of tenancy agreement, COVID-19 pandemic, residential property, tenancy agreement.

\section{INTRODUCTION}

The outbreak of the "new normal"- coronavirus in December 2019 and declaration of a pandemic in 2020 - affected every aspect of human endeavours. Costin (2020) observed that the plunging of the demand for rental properties globally caused by the pandemic and the subsequent worldwide quarantine and lockdown actions had impeded personal human and business activities and the developmental and economic growth of nations. UNCTAD, Wang \& Tang, cited in (Tanrıvermiş, 2020), opined that the outbreak of the novel coronavirus was on its 
way to becoming an eternal part of the world, human life and activities; hence the world should be prepared to integrate the "new normal".

In Nigeria, the trending approaches adopted by most business owners/investors since the advent of the "new normal" has been the deliberate actions to hold back on all plans of expansion or relocation of business offices as the stance of the pandemic is under observation. Again, the ripples arising from the lockdown policy have heavily and monstrously curtailed human rights and freedom as well as distorted rental obligations. However, the pandemic' effect is felt more in the areas of landlord and tenant relationship, as any irreconcilable needs or wishes of the parties could bring about friction. The friction could stretch the bonds that tie the parties together to the very limit and, if broken, can make tenant and landlords who are supposed to be partners in progress in the rental market suspicious of each other. In Africa, particularly Nigeria, the excessive attachment of interest and superiority to land and landed property ownership status and the recent outbreak of the Covid19 pandemic has exacerbated the ill-treatment and the undermining of the rights of the tenant by their landlords.

Hazlina et al. (2020) observed that the current COVID-19 pandemics era had made issues relating to tenancy agreement more exciting and of great concern. According to Ekpenyong, cited in (Bello et al., 2020), the prospects and benefits of residential property investment is a critical factor that helps in attracting both institutional and multinational investors to channel their resources into its development. As the users (either old or new tenants) of residential premises requires the developed properties for use, the residential property owners or investors expect returns from their investments; hence the need for a complete agreement between the property owner and the user becomes unignorable.

According to (Olayonwa, 2000), a tenancy agreement is a written agreement without a seal, executed between landlord and tenant, where the landlord transfer rights of use and possession to the tenant in a property in consideration for rental income. Though similar to a tenancy agreement, a lease agreement, on the other hand, is of longer duration but usually executed with a seal. The contents of these agreement(s) cannot be changed while it is in effect except agreed by the parties to the contract. Ankeli et al. (2017a) asserted that the breach of the terms of lease or tenancy agreement signed by the tenant usually attracted sanction following the serving of appropriate notices on the defaulting tenant by the landlords or their agents. Thus, a well-structured lease or tenancy agreement can be an alibi for a cordial tenant/landlord relationship and a necessity in the face of the current "new normal" (pandemic). For instance, solvent or insolvent tenants or lessees of business premises that are unable to use the premise for what it is intended due to the outbreak of the pandemic will naturally seek remedies that will release them from the contractual obligations as contained in the tenancy agreement. Nevertheless, where the contents of the tenancy agreement failed to incorporate clauses that protected such tenant, a problem most often ensued.

The study, therefore, evaluates the contents of lease or tenancy agreements entered into between a willing tenant and landlord using samples of such agreements from three cities in Osun, Nigeria, in order to determine the 
appropriateness or otherwise of such agreements in the face of the current "new normal" (COVID-19 pandemic) in Nigeria.

\section{LITERATURE REVIEW}

Globally, businesses are more connected now than ever before. The business ventures, operators, business assignments, and other supporting staff require accommodations to operate. The accommodation spaces required by the establishments are outrightly purchased or leased depending on the interest and capability of the establishment concern. The need for a comprehensive agreement (sales or tenancy) cannot be overemphasised in whichever way. The lockdown, evacuation, repatriation, and other measures nations adopt to curb the spread of the coronavirus have significantly impacted tenancy arrangements. As the world will never stand still, every activity in the globe will continue to be on the move; thus, those that will make the activities move need to remain at their assignment locations to face the uncertainty of the previous tenancy agreements earlier entered.

Several programmes and initiatives were initiated to minimise the effects of COVID-19 on both tenants and landlords by different nations of the world. Some countries' interventions or palliative programmes include emergency legislation that prohibits tenancy terminations or necessitated property owners to extend notice periods. The Irish government enacted the Emergency Measures in the Public Interest Act 2020, which gave a total ban on tenancy terminations and rental increment. In Spain, all tenancies were extended for six months in addition to the ban on rental hike and tenant evictions. On the other hand, landlords in the United Kingdom were also granted relief like mortgage holidays for buy-to-let landlords. The question is, - What was/is the intervention or palliative granted to tenants or landlords in Nigeria?

Ozili (2020) analysed the situation of the Covid-19 pandemic in Nigeria, the effect on the national economy and its structural causes. The study revealed that the combination of oil price decline and the effect of Covid-19 pandemic leading to economic activities stoppage due to Covid-19 preventive measures triggered economic downturn in Nigeria. The study further observed that the accommodative fiscal policies, loan support and other financial assistance offered to small households and businesses could not help. It was difficult for economic operators to freely engage in productive economic activities for fear of contracting the virus. Olapegba et al. (2020), cited in (Ozili, 2020), evaluated Nigerians' understanding and discernments of the Covid-19 pandemic. The study revealed that a reasonable number of Nigerians had misapprehensions of the pandemic as the virus was construed to be probably one of the Chinese government biological weapons against the world while others saw it as the offshoot of the $5 \mathrm{G}$ innovation. These delusions prevented many Nigerians from taking adequate preventive measures. The study suggested the intensification of evidence-based campaigns to eradicate misconceptions and promote more precautionary measures. 
However, (Noah, 2020) observed that the exponential growth in the Nigerian economy had led to the equally increasing demand for real property use, but the pandemic had a negative effect on the real property rental market. The CBO Capital Report of January 2015 cited in (Noah, 2020) put the worth of the Nigerian real estate sector at 39 billion USD and growing at $10 \%$ annually. Musa et al. (2020) reviewed existing studies on the effects and impact of the COVID-19 pandemic on urban housing, housing delivery, and affordability to establish and fill the identified gaps. The study adopted preferred reporting items for a systematic review and metaanalyses of documents. The findings of the study revealed the impact of the COVID-19 pandemic on space requirements, housing needs, security and affordability, housing development and real estate investment.

Tanrıvermiş (2020) examined the possible impacts of the COVID-19 outbreak on real estate development and management processes by evaluating the administrative and media records. The study described the effects of the pandemics as an unforeseen event that adversely affected development in the real estate subsector. It argued that sales operations of existing real estate projects, costs estimates, values, and rates of returns on existing real estate development had been negatively affected. Findings from the study further revealed a declining trend in the volume of transactions in real estate in Turkey with real estate transaction as retail facilities, office and residence transactions and the increased vacancy rate in hotels. The decline was further aggravated by the additional precautionary measures adopted by the country to mitigate the spread of the pandemic, which significantly increased running costs of business ventures and decreased property rent collection, which created losses due to the declining demand for disposable operating income and weakening investment value tends. The study concluded that relevant civil societies and other professional organisations in the country should work on the post-COVID-19 status of the real estate and construction industry as it was likely that jobs might be lost and new professional fields and jobs might emerge.

Wang (2021) adopted individual-level transaction data and a revised difference-in-differences method with nonparametric smoothing for examining the effect of COVID-19 on house prices of five US cities. The findings of the study revealed that Honolulu experienced obvious house price decline due to the pandemic, hence suggesting that a substantial reliance on service industries might be associated with higher vulnerabilities. The Estate Intel (2020) predicted the likelihood of an increase in the demand for serviced office space after the lockdown period in Nigeria as most businesses would opt for flexible options or put in serviced space instead of investing in fitting out new space with the consequential negative effect of reduction in hot desk as hot desk users might be operating more from home after the pandemic. The ambiguity surrounding the likelihood of the full reopening of businesses or workplaces has not been unrevealed as the current adaptation, and the evaluations of expert opinions by nations have not provided any useful information. Consequently, the "when" and "how" the already entered tenancy agreement can be adjusted to compensate for the effect of the "new normal, or new tenancy agreements should be secured and signed is a significant challenge 
for the total recovery of the rental market globally from the COVID-19 pandemic shock.

In order to cushion or mitigate the effect of COVID-19 on the investors' expected return, (Nwannekanma, 2020) argued that most properties in the highbrow areas of our cities that were put up for either sale or lease but were yet to get purchasers had been converted or had been in the process of conversion for easier up-takes as apartments for short stay lodgers and other similar users. The option may not be the best. However, to make quick returns that will cover up for the void period and consider the appreciable rising inflation rate, the effect of coronavirus pandemic has almost grounded the economy both at local and national levels as the nations' fragile currency has been pushed to its breaking point. In Turkey, (Tanrıvermiş, 2020) observed that, before the COVID-19 era, conditions for rental free use or deferral periods were usually forced on property owners or investors to ensure occupancy adequacy due to the availability of excess office spaces and to protect subsisting tenants. However, tenants may likely be more careful in entering into new rental agreements after the pandemic period. Tenants may prefer short term leases due to the inability to forecast rental performance and other risk factors as the current pandemic continues to ravage havoc on nations. Real property investors/owners may as well offer more flexible and friendly rental models. The flexible model will ensure shorter-term commitments for the achievement of a reasonable occupancy rate. However, failure to effect a flexible model may result in tenancy breakdown, which generates substantial costs for landlords (Pawson \& Munro, 2007). Additional void period incurs revenue costs of repair, cleaning, property reservicing, loss of rent cost during the void period and probable new reletting cost.

\section{IMPACT OF COVID-19 ON RENTAL AGREEMENT AND THE RIGHT OF TENANT}

The rental housing market in Nigerian cities is witnessing volatile cases of void resulting from the effect of the COVID-19 pandemic, and for the few ones that are yet to experience that, tenants are asking for rent relief while most establishments work from home, thereby reducing their business space requirements. According to Ankeli et al., (2017b), rental housing is a significant component and the largest single category of household expenses that help create a stable and healthy community. The heightened vulnerability of Nigerian residents or property users to COVID-19 pandemic impact was due to its sudden occurrence. The rental agreement is an agreed proviso stating the rights and obligations of both parties (the landlord and the tenant). Previously, rental agreements that were made and entered into between the landlord and the tenant made no provision for particular exigencies; hence, the coronavirus pandemic was a shock to the property market participants and was used as an alibi for the trampling of the rights of the tenants.

The Nigerian constitution and other laws relating to rental and property use in the country tend to favour and protect the tenant who is always seen as a lesser participant in the rental market despite fair and equitable right to operation. The 
laws, therefore, provided the duties, rights and privileges of each participant. The tenant is by law entitled to a written agreement. Though the agreement can be oral or written but to fulfil the Latin maxim of what is written is written (Quo scripti scripti) and what is written remains (quo scripti mante), it is always better for the agreement to be made in written form. The tenant is also entitled to be issued a receipt on the payment of rent or any other bills. The right to peaceful and quiet enjoyment of the property without unnecessary interference from the landlords or their agents is also a tenant's right. The right to a valid notice to quit and a compulsory seven days' notice to recover premises is another right of the tenant. The tenant has the right to statutory tenancy, the right to a fair hearing, and suing the landlord for trespass. The unfortunate legal ramifications and associated risk emanating from the outbreak of the coronavirus pandemic and its effects on rental housing agreement is primarily the fallout arising from a contractual rental dispute between the lessor and the lessee. The health crisis has created room for nonperformance in contractual agreement occasioned by the stringent COVID-19 regulatory policies aimed at flattening the pandemic curve. Unfortunately, none of the data obtained from the field reflected the provision of force majeure in the agreement signed between the lessor and the lessee in the study area; hence lessors are currently using the coronavirus pandemic as an alibi for trampling on the rights of the lessees.

\section{THE NATURE AND CONTENTS OF TENANCY AGREEMENT}

The contents of the tenancy agreement will include the obligations agreed upon by both the lessor and the lessee. These duties and rights need to be agreed on by the parties. Ankeli et al. (2017a) observed that every tenancy agreement or covenant had two primary purposes, which were to shield the tenant from dispossession or eviction from the property and to protect the tenant in occupation from undue interference with the use and quiet enjoyment of the premise. Provisions existed for these rights and duties that could be inferred in tenancy, even where such rights and duties were not expressly stated in the tenancy agreement. Where such actions fall due, it is assumed under the general legal principle that the implied covenants should immediately take effect except where there are contrary clauses that negate the automatic application of the implied covenant in the tenancy agreement. Ankeli et al. (2017a) further asserted that there could be instances where at the commencement of the tenancy or lease agreement expressly created relationship may not have been established between the parties to the agreement, but the operation of landlord and tenant law could be implied by the actions of the parties. Tenant implied covenants include but are not limited to the use of the premises in a tenant-like manner, paying rent, rates, and taxes, not denying the landlord's title and not committing waste. The implied covenant on the part of the landlord is quiet enjoyment of the premises, no derogation from the grant, fit for habitation and delivery of possession. The breach of any of the above covenants by the tenant may lead to eviction with its attendant consequences. 
On the other hand, the contents of a well-prepared tenancy agreement are expected to, among other things, contain the following features _ premises, habendum, reddendum, covenants, proviso and options. However, it is possible for the tenancy agreement to contain all these features but not correctly phrased. Hazlina et al. (2020) argues that a tenancy agreement without a force majeure clause gives the innocent parties a choice to use the doctrine of frustration. The doctrine of frustration is the state where a party cannot meet his/her contractual obligation due to no fault of his/her owner, but it has become practically impossible to do so as (the capability to perform has been severely affected) to seek relief from liability. Invoking the doctrine of frustration in tenancy agreement related issues in the face of the current COVID-19 pandemic is limited. Hazlina et al. (2020) and, Jayabalan (2020) opine that it is complicated to discharge contracts by way of frustration under a sudden situation as what the world is experiencing under COVID-19.

Despite the probable risks of the pandemic and legal ramifications, the decisions of the Nigerian government, just like other countries of the world and business owners to insulate their businesses from shock through the reduction in workforce, curtailing of citizens' mobility through widespread lockdown policies and the practice of social distancing with the aim to flatten the pandemic curve, have negatively affected landlord and tenant relationships due to the unfortunate fallout from the contractual dispute between the parties.

\section{METHODS}

The study adopted a survey research approach through the use of both quantitative and qualitative data. First, a reconnaissance survey of the selected cities and practising estate surveying firms was conducted to familiarise the researcher and field assistants with the study locations and determine the actual firms that managed real estates in the area. Next step was the identification of tenants whose tenancies had either expired or about to expire. Structured questionnaires were administered to the selected respondents, who comprised estate surveying firms/estate agents/landlords managing real estate in the study areas and tenants (lessees) falling within the targeted group. Opinions of only those landlords who managed their properties directly were taken in the sample.

To determine the nature and contents of the tenancy agreement entered into between landlords and tenants in Osogbo, Owode-Ede and Ede Metropolis, which forms the locations for the study, copies of tenancy agreements signed by lessors or their agents and the lessees were obtained and examined. The sample population for the study include a total of twenty-five (25) estate surveyors and valuers, and property agents. One hundred and fifty (150) tenants in Osogbo and Owode-Ede, and seventy (70) tenants in Ede Metropolis were randomly selected, and their opinions sampled through questionnaire administration. Out of the three hundred and seventy (370) questionnaires administered on the lessee (tenants), only three hundred and thirty (330) questionnaires, representing $89.2 \%$ were correctly filled and returned for analysis. The breakdown of questionnaires correctly filled and returned for each study location is as follows: a total of one hundred and thirty 
(130) questionnaires representing $86.7 \%$ of the questionnaires administered in Osogbo were retrieved and considered suitable for analysis. From Owode Ede, 140 (93\%) questionnaires were adequately filled and returned, while $60(85.7 \%)$ were filled and returned from Ede Metropolis.

In contrast, twenty (20) questionnaires representing $80 \%$ were adequately filled by the estate surveyors and property agents and returned for analysis. The primary concern of the study is the adequacy of tenancy agreements in the face of the current pandemic in the country. Hence, the questions contained in the questionnaire that required specific responses were, among others, questions on the socioeconomic and demographic characteristics of the respondents; property location; opinions of respondents on the contents of the tenancy agreement (in terms of the adequacy of the agreement with regards to the proviso and other requirements). The variables used to test rationality or otherwise of the respondents' perception were obtained from the existing body of literature. These were, however, done to see if the variables for tenancy agreement inadequacies in the study areas were the same as those mentioned in literature. The selected and used residential property types for the study that are common in the study areas are two- and three-bedroom bungalows, studio rooms, rooms and parlours (one-bedroom and sitting attached with kitchen, toilet and bath), single rooms (face-to-face) with shared facilities as common areas, kitchen, toilet and bathroom. The information obtained was later analysed using both descriptive and inferential statistical tools as frequency tables, percentages and Relative Importance Index (RII). The need to identify, appraise, aggregate and rank the respondents' perceptions concerning contents of tenancy agreement entered into between the lessor and the lessee in the face of the current pandemic (the new normal) in order to determine its adequacy or otherwise, determined the choice of the use of Relative Importance Index. The formula for RII used by Ankeli et al. (2020) and adopted for this study is as presented below:

$$
\mathrm{RII}=\frac{\sum W}{A \cdot N}=\frac{5 n_{5}+4 n_{4}+3 n_{3}+2 n_{2}+1 n_{1}}{5 N},
$$

where the variables are given the following weights: $W=$ weighting is given to each statement by the respondents and ranges from 1 to $5 ; n_{5}=$ strongly agreed; $n_{4}=$ agreed; $n_{3}=$ uncertain; $n_{2}=$ disagreed; $n_{1}=$ strongly disagreed; $A=$ higher response integer (5); and $N=$ total number of respondents.

\section{FINDINGS AND DISCUSSION OF RESULTS}

The results obtained from the analysed data collated from the study locations are presented in tabular format. The profile of the respondents showing their socioeconomic characteristics is provided in Table 1. The three study areas were purposively selected due to their strong rental transaction basis. Estate surveyors and valuers, local estate agents, and the landlords selected (who signed tenancy agreement forms obtained and completed the questionnaires) for the study are those directly managing properties in the study areas. The specific study locations 
selected for Osogbo are Okefia and Ogoluwa areas, Oke Alafia and Irewumi Estates for Owode Ede, and Okegada and Agip areas selected for Ede Metropolis. Analysis of questionnaires distributed to the respondents (lessees) based on the socioeconomic and demographic characteristics is presented in the table below.

Table 1. Demographic Profile of Respondents (Lessees)

\begin{tabular}{|c|c|c|c|c|c|}
\hline & & Osogbo & $\begin{array}{l}\text { Owode- } \\
\text { Ede }\end{array}$ & $\begin{array}{l}\text { Ede } \\
\text { Metropolis }\end{array}$ & Mean \\
\hline \multirow[t]{4}{*}{ Gender } & Male & $\begin{array}{l}105 \\
(80.8)\end{array}$ & $127(90.7)$ & $40(66.7)$ & $272(82.4)$ \\
\hline & Female & $25(19.2)$ & $13(09.3)$ & $20(33.3)$ & $58(17.6)$ \\
\hline & Total & 130 & 140 & 60 & \\
\hline & $25-35$ years & $15(11.5)$ & $10(7.1)$ & $22(36.7)$ & $47(14.2)$ \\
\hline \multirow[t]{4}{*}{ Age } & $36-45$ years & $45(34.6)$ & $45(32.2)$ & $10(16.7)$ & $100(30.3)$ \\
\hline & $46-55$ years & $60(46.2)$ & $65(46.4)$ & $23(38.3)$ & $148(44.8)$ \\
\hline & Above 56 years & $10(7.7)$ & $20(14.3)$ & $5(8.3)$ & $35(10.6)$ \\
\hline & Total & 130 & 140 & 60 & \\
\hline \multirow[t]{5}{*}{ Marital status } & Single & $15(11.5)$ & $8(5.7)$ & $21(35)$ & $44(13)$ \\
\hline & Married & $104(80)$ & $129(92.1)$ & $37(61.7)$ & $270(82)$ \\
\hline & Divorced & $6(4.6)$ & $1(0.7)$ & 0 & $7(2)$ \\
\hline & Widow/widower & $5(3.8)$ & $2(1.4)$ & $2(3.3)$ & $9(3)$ \\
\hline & Total & 130 & 140 & 60 & \\
\hline \multirow{5}{*}{$\begin{array}{l}\text { Educational } \\
\text { qualification }\end{array}$} & $\mathrm{ND} / \mathrm{NCE}$ & $20(15.4)$ & 19(13.6) & $24(40)$ & $63(19.1)$ \\
\hline & $\mathrm{HND} / \mathrm{BSC}$ & $65(50)$ & $23(16.4)$ & $18(30)$ & $106(32.1)$ \\
\hline & M.SC/M.TECH & $37(28.5)$ & $87(62)$ & $16(27)$ & $140(42.4)$ \\
\hline & $\mathrm{PhD}$ & $8(6.1)$ & $11(8)$ & $2(3)$ & $21(6.3)$ \\
\hline & Total & 130 & 140 & 60 & \\
\hline \multirow[t]{4}{*}{$\begin{array}{l}\text { Years of } \\
\text { tenancy }\end{array}$} & $\begin{array}{l}\text { Between 1-5 } \\
\text { years }\end{array}$ & $77(59.2)$ & $94(67.1)$ & $38(63.3)$ & $209(63.3)$ \\
\hline & $\begin{array}{l}\text { Between 6-10 } \\
\text { years }\end{array}$ & $46(35.4)$ & $37(26.4)$ & $16(26.7)$ & $99(30)$ \\
\hline & $\begin{array}{l}\text { Between 11-15 } \\
\text { years }\end{array}$ & $7(5.4)$ & $9(6.4)$ & $6(10)$ & $22(6.7)$ \\
\hline & Total & 130 & 140 & 60 & \\
\hline
\end{tabular}

Source: Field Survey, 2020

Table 1 shows the socioeconomic characteristics of the respondents (lessees) in the selected study areas. $82.4 \%$ of the lessees are male, while $17.6 \%$ are female, which proves male dominance in the rental market of the study areas. A majority of the respondents are in the age group of 36 to 45 years $(30.3 \%)$ and in the age group of 46 to 55 years $(44.8 \%$ ). In all, $82 \%$ of the respondents are married, Owode Ede $(92 \%)$ and Osogbo $(80 \%)$ having the highest number of married respondents. 
In terms of education, $32 \%$ have either first degree or Higher National Diploma certificates, and $42 \%$ are Masters Degree holders. The implication is that wellinformed individuals filled the questionnaires, which adds to the quality of the research conducted. Ostensibly, $63.3 \%$ of the respondents have been in the occupancy of their premises for the period of 1-5 years; hence, they have adequate knowledge of the issues at hand.

Three major types of property managers were identified in the study areas and were purposefully selected for the study. These comprised the estate surveyors and valuers, estate agents/ charlatans and landlords who preferred to manage their properties themselves. Unsurprisingly, rental transactions in the study areas continue despite the negative impact of the COVID-19 pandemic on the real property market subsector of the Nigerian economy. Table 2 shows that $55 \%$ of the property managers are Estate Surveyors and Valuers who have been in the real estate industry for more than 11 years $(40 \%)$, which implies that information obtained from the field is rich, reliable and professional. Furthermore, all the managing agents selected for the study were given total authority to find tenant, let and manage the properties in their portfolios. Hence, the property managers have the power to design and enforce tenancy agreements in a way that avoidable conflicts and litigations could be mitigated. This is congruent with the findings of Ankeli et al. (2017a).

Table 2. Types of Management Agents and Nature of Services Provided

\begin{tabular}{|c|c|c|c|c|c|}
\hline & & Osogbo & $\begin{array}{l}\text { Owode } \\
\text { Ede }\end{array}$ & $\begin{array}{l}\text { Ede } \\
\text { Metropolis }\end{array}$ & Mean \\
\hline \multirow[t]{3}{*}{ Property Manager } & Estate Surveyors & 4 & 6 & 1 & $11(55)$ \\
\hline & Estate Agents & 2 & 1 & 4 & $7(35)$ \\
\hline & Landlords & 0 & 0 & 2 & $2(10)$ \\
\hline \multirow{3}{*}{$\begin{array}{l}\text { Years of Agency } \\
\text { Experience }\end{array}$} & $1-5$ years & 2 & 2 & 1 & $5(25)$ \\
\hline & $6-10$ years & 3 & 3 & 0 & $6(30)$ \\
\hline & Above 11 years & 5 & 2 & 1 & $8(40)$ \\
\hline \multirow[t]{3}{*}{ Type of Agency services } & Find Tenant & 0 & 0 & 0 & 0 \\
\hline & Collect rent only & 0 & 0 & 0 & 0 \\
\hline & Let and manage. & 10 & 8 & 2 & $20(100)$ \\
\hline \multirow[t]{2}{*}{ Types of Agreement } & $\begin{array}{l}\text { Written } \\
\text { Agreements }\end{array}$ & 10 & 8 & 02 & $20(100)$ \\
\hline & $\begin{array}{l}\text { Oral/Implied } \\
\text { Agreements }\end{array}$ & 0 & 0 & 0 & 0 \\
\hline
\end{tabular}

Source: Field Survey, 2020. 
There is no specific standard by law that stipulates how the tenancy agreement should be worded or prepared. Hence, the parties to the agreement often resort to whatever terms of the agreement they both deemed fit. In the study area, the findings from the field revealed that the agreed terms in the tenancy agreements included rudimentary information on the tenancy. Information such as the address of the property and personal details of the parties, tenure, consideration and deadlines for payment of rentals, rates/utilities, other primary covenants of both parties, terms of termination and other terms may vary in the agreement itself. The specific interest of the study is to evaluate the adequacy or otherwise of these tenancy agreements entered into between lessor and lessee in the face of the sudden outbreak of the COVID-19 pandemic and its effect on tenancies.

It was, however, observed from all the tenancy agreements collected from the respondents and screened those provisions were not made for factors or clauses that could relieve tenants from unforeseeable supervening occurrences. In the recent past, the event has shown that occurrence of this nature often renders substantial portions of contractual obligations practically impossible to perform. Therefore, a tenancy agreement should include clauses and other precautionary measures as discontinuation of the tenancy agreement or cessation; the doctrine of frustration; force majeure; amendment/deferment or suspension of rent and assignment/surrender or underletting of the property in the face of unexpected occurrences as the coronavirus pandemic.

The factors or clauses that have been identified in the literature to determine the adequacy or otherwise of the contents of tenancy agreements in the study areas are presented in Table 3.

Table 3. Determining Factors or Clauses for the Adequacy of the Tenancy Agreement

\begin{tabular}{|c|c|c|c|c|c|}
\hline Factors/ clauses & $\begin{array}{l}\text { Strongly } \\
\text { agreed }\end{array}$ & Agreed & Undecided & Disagreed & $\begin{array}{l}\text { Strongly } \\
\text { disagreed }\end{array}$ \\
\hline Continuing obligations & $35(10.6)$ & $20(6.1)$ & $5(1.5)$ & $198(60)$ & $72(21.8)$ \\
\hline Cessation & $230(69.7)$ & $70(21.2)$ & 0 & $20(6.1)$ & $10(3.0)$ \\
\hline Doctrine of Frustration & $300(90.9)$ & $30(9.1)$ & 0 & 0 & 0 \\
\hline $\begin{array}{l}\text { Surrender, assignment or } \\
\text { underletting }\end{array}$ & $150(45.5)$ & $123(37.3)$ & 0 & $15(4.5)$ & $42(12.7)$ \\
\hline Force Majeure & $260(78.8)$ & $60(18.2)$ & $5(1.5)$ & $2(0.6)$ & $3(0.9)$ \\
\hline $\begin{array}{l}\text { Rent amendment suspension } \\
\text { /deferment }\end{array}$ & $100(30.3)$ & $150(45.5)$ & $20(6.1)$ & $40(12)$ & $20(6.1)$ \\
\hline $\begin{array}{l}\text { Are all the above clauses } \\
\text { included in the tenancy } \\
\text { agreement? }\end{array}$ & $15(4.5)$ & $20(6.1)$ & $10(3.0)$ & $15(4.5)$ & $270(81.8)$ \\
\hline
\end{tabular}

It shows that $81.8 \%$ of the respondents either disagreed or strongly disagreed with the view that, even in the event of unforeseeable supervening occurrences, the lease obligations should continue. All of the respondents (100\%) strongly agreed 
or agreed with the inclusion of the doctrine of frustration in the agreements and its invocation in a time of unexpected events that could reasonably alter the form of the contractual agreement or make the performance of contractual obligations impossible. Furthermore, the respondents at varying degrees either strongly agreed or agreed with the inclusions of clauses as force majeure, rent adjustment or deferment, and surrender or assignment of premises in the tenancy agreement. According to the respondents, the non-inclusion of these clauses put the tenants in a disadvantage position in unexpected occurrences as the current "new normal" the novel coronavirus.

The respondents' answers on tenancy agreement adequacy determining factors or clauses presented in Table 3 were further used for the analysis of the Relative Importance Index. Table 4, among others, presents the ranking factors/ clauses. Table 3 reveals the need to include the doctrine of frustration clause in tenancy agreements ranked first with an RII of 0.9818 . It implies that contracts that, after their formation, become impossible to be executed or performed due to any act beyond the control of either party can thus be frustrated with relief granted that could free the contracting parties from their contractual obligations. The next ranking factor or clause contained in a tenancy agreement that makes it adequate is force majeure with RII of 0.9467 . By conventions, it is gradually becoming obligatory for tenancy agreements to include force majeure in its provisions due to blightedness of tenancy by an act of God. It is a situation where either party can postpone, suspend, or terminate a specific obligation under the lease agreement due to an unforeseeable supervening event. In the current situation, the novel coronavirus is an unforeseeable supervening event that has altered most tenancy agreements in several countries globally, including Nigeria. Other clauses that, when inserted in a tenancy agreement, could bring about the desire remedies to tenants in the event of unforeseeable occurrences are Cessation (RII 0.8970); Surrender, assignment or underletting (RII 0.7964); Rent amendment suspension /deferment (RII 0.7636) and continuing obligations with RII of 0.4473 . It again indicated that tenants would not be willing to continue with all the tenancy agreement obligations in time of unexpected pandemic like the novel coronavirus.

Table 4. Relative Importance Index of Factors/Clauses Determining Tenancy Agreement Adequacy

\begin{tabular}{|c|c|c|c|c|c|c|c|c|}
\hline Factors & 5 & 4 & 3 & 2 & 1 & $\sum \boldsymbol{W}$ & RII & Rank \\
\hline Continuing obligations & 35 & 20 & 5 & 198 & 72 & 738 & 0.45 & $6^{\text {th }}$ \\
\hline Cessation & 230 & 70 & 0 & 20 & 10 & 1480 & 0.90 & $3^{\text {rd }}$ \\
\hline Doctrine of Frustration & 300 & 30 & 0 & 0 & 0 & 1620 & 0.98 & $1^{\text {st }}$ \\
\hline $\begin{array}{l}\text { Surrender, assignment or } \\
\text { underletting }\end{array}$ & 150 & 123 & 0 & 15 & 42 & 1314 & 0.80 & $4^{\text {th }}$ \\
\hline Force Majeure & 260 & 60 & 5 & 2 & 3 & 1562 & 0.95 & $2^{\text {nd }}$ \\
\hline $\begin{array}{l}\text { Rent amendment suspension } \\
\text { /deferment }\end{array}$ & 100 & 150 & 20 & 40 & 20 & 1260 & 0.76 & $5^{\text {th }}$ \\
\hline
\end{tabular}

Source: Field Survey, 2020 


\section{THE LESSON}

The novel coronavirus (new normal or COVID-19) was declared by the World Health Organisation (WHO) at an official capacity as a Public Health Emergency globally in January 2020. By March of the same year, it was officially declared by WHO as a global pandemic. The first index case arrived in Nigeria through an Italian who entered the country from Italy via Turkey by air in February 2020. Since the pandemic outbreak, the real property development and management subsector of the Nigeria economy has had its share of negative impact. Quarantine, lockdown, social distancing, among other similar precautionary measures, were embarked on by nations to curb the spread of the disease. The precautionary measures have significantly triggered the economic downturn, especially in Nigeria, where an average renter finds it challenging to pay for accommodation space.

Apart from impeding real estate developmental efforts primarily in real property sale operations and cost estimation, real property values (both capital and rental) and rates of return are generally at a low ebb during the pandemic era. Rent collection, review and default are significant management challenges currently facing estate surveyors and other real estate management agents in the country. It is, however, gradually becoming an issue of public discourse, especially among practitioners in the real property rental market in the face of the current pandemic. The continuous narrowing down of transaction volumes in real property markets, such as increasing vacancy rates in shops and hotels, retail facilities, office and residential operations, dipping demand for property use and escalating management and other operating costs, are areas of great concern. The new normal seems to transform the property market, especially in the commercial real estate sector, which may bring about an ambivalent attitude among investors.

Further change is expected in the real property development and management (rental and contracts) subsector. It is therefore expected that after the pandemic, there will be a modern innovative technological eruption in the real property development and management subsector. Tanrivermiş (2020) opined that there would be an increase in smart buildings and technologies that could encourage fewer direct contacts in buildings and structures, increasing development of ecommerce (in real estate) marketing and shrinking hot desk office demand in favour of home office or flexible working phenomena. Hence, real estate professionals and other stakeholders must be ready to embrace modern tools that will help plan, coordinate, and rearrange real estate management activities.

\section{CONCLUSIONS}

As an all-encompassing framework, tackling real estate development and management problems, especially those relating to real property agency issues, requires all stakeholders' collaborative efforts, particularly the lessor and lessees. The study, therefore, evaluates the adequacy or otherwise of tenancy agreements entered between lessors and lessees in the face of the current new normal. The study identified five factors or clauses in the literature that would need to be included in 
any tenancy agreement to make it protective and adequate. Findings of the study revealed that the inclusion of the doctrine of frustration clause in the tenancy agreement was ranked first by the respondents. However, the statement is consistent with Hazlina et al. (2020), who opined that only the court could decide if a contract were frustrated or otherwise. The study further showed that the identified relevant tenancy agreement adequacy factors or clauses were not reflected in most of the agreements sampled as $81.8 \%$ and $4.5 \%$ of the respondents strongly disagreed and disagreed with their existence in the agreements signed. The implication of entering into agreements that are defectively worded, especially in the rental market, is the frictions that usually arises between the lessor and the lessee. Apart from destroying the landlord/tenant relationship, it has a negative impact on the property as aggrieved tenant transfers their anger on the property. Therefore, the study recommends a thorough reassessment of tenancy agreement contents in the state, especially those issued by charlatans in the real property market. Real estate professionals and specialist in other related disciplines should develop a minimum standard for tenancy agreement preparation. All tenancy agreement should contain clauses that protect tenants from a sudden outbreak of supervening events or act of God that may be beyond the control of the contracting parties.

\section{FUTURE RESEARCH AREAS}

The current study is restricted to a trifling section of a state in Nigeria. The study covers the adequacy of tenancy agreements at the time of the pandemic. Future studies can be conducted to have a more comprehensive geographical and conceptual coverage in the country to evaluate the contents of the tenancy agreement and its administration among real estate professionals.

\section{REFERENCES}

Ankeli, I. A., Nuhu, M. B., Popoola, N. I., Ankeli, U. C., \& Ojeniyi, A. S. (2020). Gender Disparity in Land Ownership: An Invitation to National Underdevelopment. International Journal of Creative Research Thoughts, 8(6), 4176-4185.

Ankeli, I. A., Dabara, I. D., Omotehinshe, J. O., Omoyosi, G. A \& Agidi, M. O. (2017a). Evaluation of the Causes and Consequences of Tenant Eviction in Ede Metropolis, Nigeria. International Journal of Arts \& Sciences, 9(4), 149-158.

Ankeli, I. A., Dabara, I. D., Omotehinshe, J. O., Lawal, O. K., Odeyomi, F. G., \& Adebowale, A. P. (2017b). Affordable and Acceptable Mass Housing Delivery: A Panacea to the Nigeria Housing Problem. In Conference of the International Journal of Arts \& Sciences, 10(01), 31-38.

Bello, N. A., Adepoju, A. S., \& Durosinmi, W. A. (2020). Factors Influencing Rental and Capital Values of Residential Investment Property in Abuja, Nigeria. INTREST - International Journal of Real Estate Studies, 14(1), 102-109.

Costin, J. (2020, May 7). Covid-19: The Impact on the Global Rental Market. The Employment Condition Abroad International (ECA). https://www.eca-

international.com/insights/articles/may-2020/covid-19-the-impact-on-the-global-rental-market

Estate Intel (2020). Nigerian Real Estate and COVID in 19 Slides. https://estateintel.com/insights/nigerian-real-estate-and-covid-in-19-slides 
Hazlina, M. P., Farihana A. R., Nor, L. A., \& Noorsaliza, A. N. (2020). COVID 19: The Application of the Doctrine of Frustration in a Tenancy Agreement. Articles Compilation: Thesis in 5 Minutes. MNNF Publisher.

Musa, G. U., Adeogun, A. S., and Durosinmi, W. A. (2020). Effects of COVID-19 on Urban Housing Delivery and Affordability in Nigeria. INTREST - International Journal of Real Estate Studies 14(S2), 195-204.

Nwannekanma, B. (2020, August 24). COVID-19 Triggers Conversion of Properties to Rental Apartments. Guardian Newspapers.

Noah, I. (2020). Nigeria's Real Estate Market. Property Wire. https://www.propertywire.com/blog/nigerias-real-estatemarket/

Jayabalan, S. (2020). The Legality of Doctrine of Frustration in the Realm of Covid-19 Pandemic. Sociological Jurisprudence Journal, 3(2), 84-90. https://doi.org/10.22225/scj.3.2.1900.84-90

Olayonwa, G. O. (2000). Property Management Principles and Practice. Debo Publishing Company, Iwo, Nigeria.

Ozili, P. K. (2020). COVID-19 Pandemic and Economic Crisis: The Nigerian Experience and Structural Causes. MPRA Paper No. 103131.

Pawson, H. \& Munro, M. (2007). What Causes Tenancy Failure and can Choice Help? Analysing Tenancy Sustainment in British Social Rented Housing; Housing Studies Association Conference, University of York, 11-13 April. Accessed on 03/04/2014 at http://www.york.ac.uk/chp/hsa/papers/spring07/pawson.doc

Tanrıvermiş, H. (2020). Possible Impacts of COVID-19 Outbreak on Real Estate Sector and Possible Changes to Adopt: A Situation Analysis and General Assessment on Turkish Perspective. Journal of Urban Management, 9(3), 263-269. https://doi.org/10.1016/j.jum.2020.08.005

Wang, B. (2021). How Does COVID-19 Affect House Prices? A Cross-City Analysis. Journal of Risk and Financial Management, 14(2), 47. https://doi.org/10.3390/jrfm14020047

\section{AUTHORS' SHORT BIOGRAPHIES}

Anthony Ikpeme Ankeli holds National and Higher National Diploma; Bachelor of Science Degree; Postgraduate Diploma; Masters of Technology Degree (M. TECH) in Estate Management from the prestigious Kaduna Polytechnic, Kaduna, Joseph Ayo Babalola University Ikeji Arakeji and the Federal University of Technology Akure, Nigeria. He also holds Postgraduate Diploma in Education from Usmanu Danfodiyo University, Sokoto. Ankeli is an Associate Member of the Nigeria Institution of Estate Surveyors and Valuers and registered as an Estate Surveyors and Valuers with the Estate Surveyors and Valuers Registration Board of Nigeria. Ankeli has worked with Olu Akinyebo and Co; Mosaku and Co; Arewa Prime Properties and HABS and Associates firms of estate surveying and valuation based in Kaduna, Nigeria. Ankeli was the former Head, Department of Estate Management and Valuation, the Federal Polytechnic Ede. He has attended conferences, presented papers and published in local and internationally recognised journals. Ankeli is a lecturer in the Department of Estate Management and Valuation, Federal Polytechnic Ede, Osun State, Nigeria, Principal Partner of 'Tony Ankeli and Associates and currently a PhD candidate of the Federal University of Technology, Minna, Nigeria.

Email: thonyankeli@gmail.com

ORCID ID: https://orcid.org/0000-0002-8190-3572

Muhammad Bashar Nuhu is the first to acquire a PhD in Estate Management and Valuation and the first Professor of Estate Management and Valuation in northern Nigeria. He holds Higher National Diploma in Architecture from Kaduna Polytechnic, a Bachelor of Technology Degree, Masters of Technology Degree and a PhD in Estate Management and Valuation from the Federal University of Technology, Minna, Nigeria. Nuhu is a Professor and two-time Head of the Department of Estate management and valuation, the Federal University of Technology Minna and the pioneer Head of Estate Management and Valuation Department, Bayero University, Kano. Prof. Nuhu has served and still serving in various committees in the University. He is currently the Director of the Centre for Human Settlements and Urban Development at the University. He started his civil servant carrier with 
the Local Government Service Commission and rose through the ranks to Director of Works and Housing in Niger State, Nigeria, before joining the services of the Federal University of Technology Minna. Nuhu is a fellow of the Nigeria Institution of Estate Surveyors and Valuers (NIESV) and registered as an Estate Surveyors and Valuers with the Estate Surveyors and Valuers Registration Board of Nigeria, principal partner of M.B Nuhu and Company, a former Commissioner for Tertiary Education in Niger State, a former Niger state branch chairman of NIESV, former national education committee chairman and the Honorary Director-General of NIESV Learning Centre and Chairman Implementation Committee of NIESV Learning Centre and a Board Member of Estate Surveyors and Valuers Registration Board of Nigeria. He has attended conferences, presented papers and published in local and internationally recognised journals.

Naomi Ijaduola Popoola is a senior lecturer in the Department of Estate Management and Valuation, the Federal University of Technology, Minna, Nigeria. She holds a National Diploma in Architecture from Federal Polytechnic Nassarawa, a Bachelor of Technology Degree in Estate Management, Masters of Technology Degree, and a PhD from the Federal University of Technology, Minna, Nigeria. Before joining the services of the Federal University of Technology Minna, she has worked with ROFEGA Consultants in Jos and Sokoto State Housing Cooperation. She has attended conferences, presented papers and published in national and internationally recognised journals.

Olurotimi Adebowale Kemiki is a Professor and Head, Estate Management and Valuation Department, Federal University of Technology Minna. He had worked at both public and private establishments such as Diya, Fatimilehin, Chevron and Lagos state valuation office. He joined the service of Federal University of Technology, Minna in 2002 as Assistant Lecturer and rose to the rank of Professor of Estate Management and Valuation in 2019. He emerged the nationwide Best Candidate in NIESV Direct Final Exams in 2001 and became a Fellow in 2015. He was the Chairman National Education Committee (2016-2019) and introduced the Study Pack and the use of Biometric Technology, to improve the standard and integrity of NIESV exams. He also introduced a national quiz competition which has become a ritual during our annual conference. He also served as Member of Council (2015-2019), Branch Secretary NIESV Niger (2005-2009), Branch Chairman (2015-2019), and led the branch to emerge the best performing branch in Nigeria during 2016/2017 Council year. $\mathrm{He}$ is an alumnus of Federal University of Technology, Minna, Experiential Classroom School of Business Oklahoma State University USA, Dubai Real Estate Institute Dubai. He is a member of International Society on Urban Health, USA, Association for the Advancement of Cost Engineering USA, Nigerian Environmental Society. He was National Vice President Federal University of Technology, Minna Alumni from 2008 to 2012 and presently a trustee of the Alumni. He is an awardee of several awards, recognitions and honours.

Sunday Okuoma Okoh holds a Bachelor of Science and Masters of Science Degree in Estate Management and Valuation from the University of Lagos and an MBA from the University of Ilorin, Nigeria. He is an Associate Member of the Nigeria Institution of Estate Surveyors and Valuers and registered as an Estate Surveyors and Valuers with the Estate Surveyors and Valuers Registration Board of Nigeria and the principal partner of Okoh and Associates. Okoh is a versatile real estate consultant, lectures at the Federal Polytechnic, Bida, Niger state and the immediate past Head, Department of Estate Management and Valuation, Federal Polytechnic, Bida, Niger state. He has attended conferences, presented papers and published in national and internationally recognised journals. Okoh is a PhD candidate of the Federal University of Technology, Minna, Nigeria.

Joseph Olusegun Omotehinshe holds Higher National Diploma in Architecture from the Federal Polytechnic Nassarawa, a Bachelor of Science in Building and a Masters of Science Degree in Construction Management from Obafemi Awolowo University. Omotehinshe is a Registered Builder and currently lectures in the Department of Building Technology, Federal Polytechnic Ede. He is the immediate past Head of Department of Building Technology and a PhD candidate of the Obafemi Awolowo University Ile Ife and has attended conferences, presented papers and published in national and internationally recognised journals. 